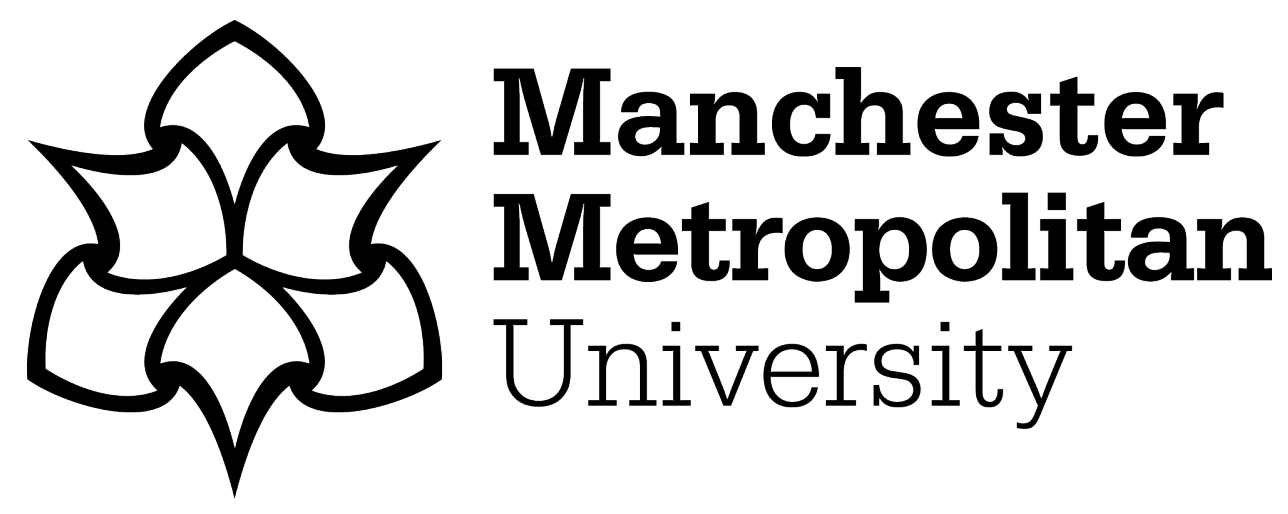

Pacheco, José Fernando, Silveira, Luís Fábio, Aleixo, Alexandre, Agne, Carlos Eduardo, Bencke, Glayson A, Bravo, Gustavo A, Brito, Guilherme RR, Cohn-Haft, Mario, Maurício, Giovanni Nachtigall, Naka, Luciano N, Olmos, Fabio, Posso, Sérgio R, Lees, Alexander ORCID logoORCID: https://orcid.org/0000-0001-7603-9081, Figueiredo, Luiz Fernando A, Carrano, Eduardo, Guedes, Reinaldo C, Cesari, Evaldo, Franz, Ismael, Schunck, Fabio and Piacentini, Vitor de Q (2021) Annotated checklist of the birds of Brazil by the Brazilian Ornithological Records Committee-second edition. Ornithology Research, 29.

Downloaded from: https://e-space.mmu.ac.uk/628839/

Version: Accepted Version

Publisher: Springer Nature

DOI: https://doi.org/10.1007/s43388-021-00058-x

Please cite the published version 


\section{Annotated checklist of the birds of Brazil by the Brazilian Ornithological Records}

Committee - second edition

José Fernando Pacheco ${ }^{1,3,4^{*}}$, Luís Fábio Silveira ${ }^{1,2,5}$, Alexandre Aleixo ${ }^{1,2,6}$, Carlos Eduardo Agne $^{1,2}$, Glayson A. Bencke ${ }^{1,7}$, Gustavo A. Bravo ${ }^{1,2,8}$, Guilherme R. R. Brito ${ }^{1,2,9}$, Mario CohnHaft ${ }^{1,2,10}$, Giovanni Nachtigall Maurício ${ }^{1,2,11}$, Luciano N. Naka ${ }^{1,2,12}$, Fabio Olmos ${ }^{1,2,13}$, Sérgio R. Posso $^{1,2,14}$, Alexander C. Lees ${ }^{1,15,16}$, Luiz Fernando A. Figueiredo ${ }^{1,17}$, Eduardo Carrano ${ }^{1,18}$, Reinaldo C. Guedes ${ }^{19}$, Evaldo Cesari ${ }^{20}$, Ismael Franz ${ }^{1,21}$, Fabio Schunck ${ }^{1}$, Vitor de Q. Piacentini ${ }^{1,2,4,22}$

${ }^{1}$ Brazilian Ornithological Records Committee, Brazilian Ornithological Society, Brazil

${ }^{2}$ Taxonomy Subcommittee, Brazilian Ornithological Records Committee, Brazil

${ }^{3}$ Oikos Pesquisa Aplicada Ltda, Rio de Janeiro, RJ, Brazil

${ }^{4}$ South American Classification Committee, American Ornithological Society.

${ }^{5}$ Seção de Aves, Museu de Zoologia da Universidade de São Paulo, São Paulo, SP, Brazil

${ }^{6}$ Finnish Museum of Natural History, University of Helsinki, Finland

${ }^{7}$ Museu de Ciências Naturais, Secretaria de Meio Ambiente e Infraestrutura, Porto Alegre, RS, Brazil

${ }^{8}$ Department of Organismic and Evolutionary Biology and Museum of Comparative Zoology, Harvard University, Cambridge, MA, USA

${ }^{9}$ Laboratório de Ornitologia e Bioacústica Catarinense - LABOAC, Departamento de Ecologia e Zoologia, Universidade Federal de Santa Catarina, Florianópolis, SC, Brazil

${ }^{10}$ Instituto Nacional de Pesquisas da Amazônia, Manaus, AM, Brazil

${ }^{11}$ Universidade Federal de Pelotas, Pelotas, RS, Brazil

${ }^{12}$ Laboratório de Ornitologia, Universidade Federal de Pernambuco, Recife, PE, Brazil

${ }^{13}$ Permian Brasil, São Paulo, SP, Brazil

${ }^{14}$ Laboratório de Ecologia, Sistemática e Conservação de Aves Neotropicais - LESCAN, Universidade Federal do Mato Grosso do Sul, Campus Três Lagoas, MS, Brazil

${ }^{15}$ Department of Natural Sciences, Manchester Metropolitan University, Manchester, United Kingdom

${ }^{16}$ Cornell Lab of Ornithology, Cornell University, Ithaca, NY, USA

${ }^{17}$ Centro de Estudos Ornitológicos, São Paulo, SP, Brazil

${ }^{18}$ Laboratório de Ecologia e Conservação, Pontifícia Universidade Católica do Paraná, Curitiba, PR, Brazil

${ }^{19}$ WikiAves - A Enciclopédia das Aves do Brasil

${ }^{20}$ Salesforce, São Paulo, SP, Brazil 
${ }^{21}$ Departamento de Zoologia, Universidade Federal do Rio Grande do Sul, Porto Alegre, RS, Brazil

${ }^{22}$ Departamento de Biologia e Zoologia and Programa de Pós-Graduação em Zoologia, Instituto de Biociências, Universidade Federal de Mato Grosso, Cuiabá, MT, Brazil

* Corresponding author: cbro@cbro.org.br

J.F. Pacheco ORCID: 0000-0002-2399-7662

L.F. Silveira ORCID: 0000-0003-2576-7657

A. Aleixo ORCID: 0000-0002-7816-9725

C.E. Agne ORCID: 0000-0001-6195-4092

G.A. Bencke ORCID: 0000-0002-3809-8547

G.A. Bravo ORCID: 0000-0001-5889-2767

G.R.R. Brito ORCID: 0000-0003-4445-711X

M. Cohn-Haft ORCID: 0000-0002-5241-2344

G.N. Mauricio ORCID: 0000-0002-2755-3962

L.N. Naka ORCID: 0000-0002-7716-3401

F. Olmos ORCID: 0000-0003-3832-6455

S.R. Posso ORCID: 0000-0002-7823-9068

A.L. Lees ORCID: 0000-0001-7603-9081

L.F.A. Figueiredo ORCID: 0000-0001-5235-1572

E. Carrano ORCID: 0000-0002-6657-8345

R.C. Guedes ORCID: 0000-0002-2477-0902

E. Cesari ORCID: 0000-0003-1700-051X

I. Franz ORCID: 0000-0003-3382-0403

F. Schunk ORCID: 0000-0002-0974-2655

V.Q. Piacentini ORCID: 0000-0003-1571-2222

Communicated by L. Bugoni

\begin{abstract}
An updated version of the checklist of birds of Brazil is presented, along with a summary of the changes approved by the Brazilian Ornithological Records Committee's Taxonomy Subcommittee since the first edition, published in 2015. In total, 1971 bird species occurring in Brazil are supported by documentary evidence and are admitted to the Primary List, 4.3\% more than in the previous edition. Eleven additional species are known only from undocumented records (Secondary List). For each species on the Primary List, status of occurrence in the country is provided and, in the case of polytypic species, the respective
\end{abstract}


subspecies present in Brazilian territory are listed. Explanatory notes cover taxonomic changes, nomenclatural corrections, new occurrences and other changes implemented since the last edition. Ninety species are added to the Primary List as a result of species descriptions, new occurrences, taxonomic splits and transfers from the Secondary List due to the availability of documentation. In contrast, eight species are synonymized or assigned subspecific status and thus removed from the Primary List. In all, 293 species are endemic to Brazil, ranked third among the countries with the highest rate of bird endemism. The Brazilian avifauna currently consists of 1742 residents or breeding migrants, 126 seasonal non-breeding visitors and 103 vagrants. The category of vagrants showed the greatest increase (56\%) compared to the previous list, mainly due to new occurrences documented in recent years by citizen scientists. The list updates the diversity, systematics, taxonomy, scientific and vernacular nomenclature, and occurrence status of birds in Brazil.

Keywords biodiversity, classification, endemism, species list, subspecies, taxonomy

\section{Introduction}

The Annotated Checklist of the birds of Brazil (Piacentini et al. 2015) was a watershed publication that culminated a decade of work by the Brazilian Ornithological Records Committee (hereafter CBRO) in revising and updating the accepted list of Brazilian birds. Before then, between 2005 and 2014, CBRO had published 11 previous editions of the list. However, these earlier editions were not published in a scientific journal, nor did they contain explanatory notes with supporting references. Here, we present the second edition of the Annotated Checklist (thirteenth in the historical series), incorporating changes approved between January 2016 and May 2021 by the CBRO Taxonomy Subcommittee, in addition to adding species recently described or recorded for the first time in Brazil.

The list is an open access scientific resource made available by CBRO for the benefit of many different potential users, including scientists, birders, wildlife managers, government agencies, educators and students, among others. In recent years, the CBRO checklist has been used as the baseline avian taxonomy in several initiatives carried out in Brazil, such as: i) the Red List assessment of Brazilian fauna (ICMBio 2018); ii) the largest citizen science data portal on Brazilian birds on the internet (www.wikiaves.com.br); iii) state-level consolidation of local lists of birds (e.g., Nunes et al. 2017; Franz et al. 2018); and iv) organization and management of important scientific collections in the country (e.g., Museu Paraense Emílio Goeldi - MPEG, Muzeu de Zoologia da Universidade de São Paulo - MZUSP, Museu de Ciências Naturais $\mathrm{MCN})$. In this way, $\mathrm{CBRO}$ has provided a service that contributes to the development and dissemination of knowledge about Brazilian biodiversity and fulfills the purpose of facilitating communication between different users, going beyond the limits of scientific and academic circles. 
In addition, as highlighted in previous editions of the checklist, the number of bird species recognized in Brazil by $\mathrm{CBRO}$ has increased substantially over the last few years. This is mainly due to recognition of species-level taxa previously considered subspecies following publication of studies using modern molecular techniques in combination with traditional morphological and bioacoustic analyses (Piacentini et al. 2015). This trend is expected to continue for years, perhaps decades, to come, as progress is made with ongoing taxonomic studies coupled with intensifying biodiversity inventory efforts, especially driven by contributions of citizen scientist birders. Therefore, it is essential that the checklist undergoes periodic updates to keep up with the dynamics of scientific knowledge about Brazilian avifauna. This way, it will continue to serve as an up-to-date reference on the diversity, systematics, taxonomy, nomenclature and occurrence status of Brazilian birds.

\section{Methods}

Criteria and procedures for inclusion of species and for introduction of taxonomic changes in the list are those described in Piacentini et al. (2015, p. 93), with some adjustments (specified below). The CBRO system for scrutinizing taxonomic cases is based on discussion and subsequent vote by the 11 members of the Taxonomic Subcommittee. An overview of the structure, general procedures and definitions adopted in the list is provided below.

\section{List of species}

The CBRO list is structured in three main sections, as follows:

Primary List - Species for which there is at least one Brazilian record with associated documentary evidence. Documentation in this context means evidence available for independent verification, in the form of a complete or partial specimen, or rich media in the form of photographs, audio or video, which allow the unambiguous identification of the taxon (see also Carlos et al. 2010). Unlike Piacentini et al. (2015), in the present edition published records obtained with the use of geolocators or other remote tracking devices (henceforth, RTD; see a review of these devices in Marra et al. 2018) are regarded as acceptable evidence for admission to the Primary List. Such evidence is considered sufficiently robust and reliable as long as the precision of each method is observed, and especially where there is a negligible chance of identification errors arising from tagging birds in mixed breeding colonies of phenotypically similar species.

Secondary List - Species for which published national records exist, but with either unknown or unavailable documentary evidence. All species included in this list are considered to be of probable occurrence in Brazil, as inferred from their distribution and dispersal patterns established based on currently available information. 
Tertiary List - Species for which there are specific published national records, but with questionable or invalid documentary evidence, in addition to being of unlikely occurrence in Brazil.

Herein, only the primary and secondary lists are presented as Supplementary Information, whereas the tertiary list can be accessed on the CBRO website at http://www.cbro.org.br/listas/.

\section{General criteria and definitions}

The current checklist is an update of the last version published by CBRO (Piacentini et al. 2015). Species added to the list are those recently recorded for the first time in the country based on evidence accepted by CBRO, as well as those recently described or validated at the species level based on scientific literature with supporting data considered robust by the CBRO Taxonomy Subcommittee.

The current list follows the systematic order of the South American Classification Committee (SACC) of the American Ornithological Society (Remsen et al. 2021), as of the 19 January 2021 update. This is because both CBRO and SACC use the same basic monophyly criterion in delimitation of large groups of birds (e.g., Orders, Families and Subfamilies), and which is based on the same phylogenetic studies focused on these large groups (e.g., Tello et al. 2009; Ohlson et al. 2013; Fuchs and Pons 2015). However, regarding species-level taxonomy, we notice that the CBRO and SACC lists differ to some extent, resulting in distinct species totals for Brazil. This discrepancy arises from the use of different species concepts by CBRO and SACC, the latter adhering to the Biological Species Concept and associated criteria for species delimitation (see below for the criteria adopted by the CBRO).

We regularly and systematically searched the scientific and birding literature covering ornithological inventories, species lists and distributional information for new country records. Acceptance of new occurrences for the country is generally based on publications in which the circumstances of the original records are presented. Unpublished records with documental evidence deposited in citizen science web portals and online databases (WikiAves, Xeno-canto, and Macaulay Library/eBird) were also accepted when the authors of the media agreed with their incorporation into the list.

National bird records are those considered to be obtained unequivocally in Brazilian territory (Straube 2003) or within the limits of the Brazilian Baseline, which include the territorial sea (12 nautical miles), the contiguous zone (24 nautical miles), the exclusive economic zone (200 nautical miles), and the continental shelf, in accordance with the provisions of Law No. 8617, of 04 January 1993 (Carvalho 1999; Straube 2003).

To assess the limit and validity of species, CBRO adopts the General Lineage Species Concept (de Queiroz 2005; Aleixo 2007). Whenever new evidence that implies taxonomic 
changes at the species level is published, CBRO seeks to interpret them in the context of recent advances in the fields of speciation genetics, reproductive isolation, directional selection and hybridization dynamics (Gill 2014; Ottenburghs et al. 2017; Padial and De la Riva 2020). According to the rationale proposed by Gill (2014), the "null hypothesis" behind the taxonomic decisions at the species level adopted by CBRO can be summarized as follows: sister, distinct and reciprocally monophyletic populations that are essentially reproductively isolated, i.e., do not interbreed freely if they occur in sympatry. Special care is taken not to implement taxonomic changes that are considered incomplete or probably temporary due to a lack of information about a particular taxon or a set of taxa that has been subject to recent systematic and/or taxonomic review (e.g., Mallet-Rodrigues and Gonzaga 2015; Manthey et al. 2016; Musher and Cracraft 2018).

The basis of the taxonomic decisions and treatments adopted by CBRO are scientific articles published in peer-reviewed journals. In particular, proposals derived from studies conducted under a "multi-character" approach and that incorporate as much phenotypic and genetic evidence as possible are more likely to be adopted by the Committee (Sangster 2018). Regarding molecular characters, studies that focus on several genes at a genomic level take precedence over those that rely on smaller sets of genes or are based on a single locus (e.g., mitochondrial DNA). It is important to note that the adoption of a taxonomic treatment by CBRO does not necessarily imply unanimous approval by members of the Taxonomy Subcommittee. Adoption of a new taxonomic proposal requires at least $70 \%$ approval by the voting members. Thus, there are situations in which one or more authors of this work disagree with the treatment adopted here.

Common English names follow those of the eBird/Clements Checklist of Birds of the World (Clements et al. 2019), except in cases where the treatment adopted by CBRO differs from that in this source.

The CBRO list, as traditionally implemented since the first version, continues to indicate the full authorship (even when multiple authors are involved) of taxa at all levels, from higher-level classification through to species and subspecies. In addition, the pattern of seasonal occurrence in the country is indicated for each species on the primary list by a letter code according to the following categories and definitions:

$\mathrm{BR}=$ breeding resident (either sedentary or migratory; evidence of regular breeding in the country available);

$\mathrm{VI}=$ regular non-breeding visitor from the south $[\mathrm{VI}(\mathrm{S})]$, from the north [including North America, the Caribbean and the northernmost part of South America; VI(N)], from the east [i.e., the Old World; VI(E)] or from areas west of the Brazilian territory [VI(W)];

$\mathrm{VA}=$ vagrant (of irregular and incidental occurrence in Brazil; may be a regular migrant in neighboring countries), coming from the south [VA(S)], from the north [VA(N)], 
from the east $[\mathrm{VA}(\mathrm{E})]$ or from the west $[\mathrm{VA}(\mathrm{W})]$, or originating from an unspecified direction [VA];

Eventually, species indicated as visitors may be accompanied by "BR". This denotes that some reproduction has been reported in the country, but that most records are still derived from visitors.

Such abbreviations are eventually combined with the following:

\# = status assumed but not confirmed.

$\mathrm{Ex}=$ extinct in national territory (at least in the wild);

En = endemic to Brazil (i.e., not known to occur outside the country's political boundaries);

In $=$ introduced and now naturalized exotic or domestic species, within Brazil or from neighboring countries.

Since the concept of endemism depends on the spatial scale considered (Fattorini 2017), it should be noted that we used a regional (i.e., political) rather than an areal definition of endemism to assess the number of endemic bird species in Brazil (see Peterson and Watson 1998).

\section{Subspecies}

As in the previous edition (Piacentini et al. 2015), with the purpose of assisting in the understanding of the biological diversity of Brazilian birds, we continue to tentatively list the subspecies of birds in Brazil. This information aims to point out taxonomic complexes in need of revision and restricted range taxa/populations to be considered in public conservation policies. Inclusion of these subspecies is purely instrumental and should not be understood as a taxonomic validation by CBRO, especially given that concepts of species based on evolutionary lineages (General Phyletic, Phylogenetic, Evolutionary and the like) do not necessarily attribute any evolutionary meaning to subspecies. Thus, subspecies are included in the list as an indication of potentially valid taxa existing in the country based on their acceptance by at least one of the following recent reference works: Grantsau (2010); eBird/Clements Checklist of Birds of the World (Clements et al. 2019); The Howard \& Moore Complete Checklist of the Birds of the World (Dickinson and Remsen 2013; Dickinson and Christidis 2014); Handbook of the Birds of the World (del Hoyo et al. 1992-2013; supplemented by updates in del Hoyo et al. 2014, 2016), and IOC World Bird List 10.2 (Gill et al. 2020).

We included in the list some subspecies omitted from the reference works above but for which no explicit assessment of their validity has been published since their original description. In contrast, we excluded subspecies listed in reference works whenever their connection to Brazil was interpreted as erroneous (e.g., Dendrocincla fuliginosa ridgwayi). Similarly, we excluded subspecies cited in the reference works but whose validity has been 
challenged in recent taxonomic assessments that made use of species-definition criteria directly comparable to those adopted by CBRO (e.g., Dendrocincla fuliginosa trumaii; Schultz et al. 2019). For all controversial cases, we produced explanatory notes (see Supplementary Information).

All subspecies included in the checklist were combined hierarchically with their respective species, sometimes requiring adjustments in taxonomic combinations when the CBRO treatment of a particular species differs from that in the reference works. The order of the subspecies follows the traditional treatment adopted in zoological catalogs, i.e., from north to south and from west to east (e.g., Ridgway 1901; Hellmayr 1927).

\section{Explanatory notes}

Explanatory notes were included ad libitum whenever we believe that the taxonomic treatment adopted by CBRO or the acceptance of the occurrence of a certain species in Brazil deserved a more detailed explanation (SI). In general, the notes address new species occurrences, new taxonomic treatments and nomenclatural corrections published after Sick (1997) and, especially after Piacentini et al. (2015). For species in the Secondary List, we provide information on the original record (location, date) or indicate the source that reviews the existing undocumented records (Supplementary Information S1).

\section{Results}

This new edition of the Annotated Checklist of the birds of Brazil recognizes 1971 species on the Primary List (SI). Of this total, 1066 (54\%) are monotypic, i.e., without any subspecies or "geographic races", while 905 (46\%) are polytypic, i.e., divided into subspecies (trinomials) in at least one recent reference work. Among the polytypic species, 591 are represented in Brazil by more than one subspecies and 314 by a single one. In total, there are 3064 valid or potentially valid forms (distinct species and subspecies) occurring in the Brazilian territory. A further 11 species, for which records are based on observations only, make up the Secondary List (Supplementary Information S1). Among the main higher taxa, 33 orders, 102 families, 85 subfamilies and 732 genera are recognized as occurring in Brazil (Supplementary Information S1).

A summary of the main changes introduced in this new edition of the checklist is presented below. The sections "Genuine additions", "Additions due to taxonomic splits", "Transfers from the Secondary List" and "Removals" deal with cases that affect the number of species in the Primary List compared to Piacentini et al. (2015). The remaining sections describe changes that do not affect species totals between the current and last versions of the checklist. 


\section{Genuine additions (new species and new occurrences)}

In this new edition of the checklist, 40 species represent genuine additions to the Primary List. Five additions (Campylopterus calcirupicola, Megascops stangiae, M. alagoensis, Trogon muriciensis, and Sporophila iberaensis) are new species described after publication of Piacentini et al. (2015), the first four from Brazil and the latter from elsewhere in South America. The remaining 35 species (Table 1) constitute new distributional occurrences that are either unprecedented or preceded only by speculative or questionable records in Brazil. Most of them represent vagrant individuals (e.g., Cuculus canorus, Porphyrio alleni, Tringa glareola), but some may be regular visitors (e.g., Calidris mauri, Progne dominicensis, P. cryptoleuca) or residents in infrequently visited frontier areas (e.g., Hydropsalis heterura, Lophornis cf. delattrei, Urubitinga solitaria, Grallaria guatimalensis, Grallaricula nana, Phyllomyias weedeni, Catharus aurantiirostris).

Table 1 Species added to the list of Brazilian birds based on recently reported occurrences. The state or archipelago where these new records were obtained are indicated, along with the type of documentary evidence supporting inclusion in the Primary List. New genera for the country are shown in bold

\begin{tabular}{|c|c|c|}
\hline Species & State/archipelago $^{a}$ & Documentary evidence $^{\mathrm{b}}$ \\
\hline Cuculus canorus $^{\mathrm{c}}$ & $\mathrm{FN}$ & Photograph \\
\hline Hydropsalis heterura & RR & Specimen \\
\hline Chordeiles gundlachii & $\mathrm{RR}, \mathrm{AM}$ & RTD position \\
\hline Lophornis cf. delattrei & $\mathrm{AC}$ & Photograph \\
\hline Porphyrio alleni $^{\mathrm{c}}$ & $\mathrm{FN}$ & Photograph \\
\hline Porzana carolina ${ }^{\mathrm{c}}$ & RJ & Photograph \\
\hline Charadrius sp. $^{\mathrm{c}}$ & $\mathrm{RS}$ & Photograph \\
\hline Calidris ferruginea & CE, MA & Photograph \\
\hline Calidris minuta $^{\mathrm{c}}$ & FN & Photograph \\
\hline Calidris mauri $^{\mathrm{c}}$ & RJ & Photograph \\
\hline Phalaropus lobatus ${ }^{\mathrm{c}}$ & RJ & Photograph \\
\hline Tringa glareola ${ }^{\mathrm{c}}$ & $\mathrm{FN}$ & Photograph \\
\hline Chroicocephalus ridibundus & SPSP & Photograph \\
\hline Leucophaeus modestus ${ }^{\mathrm{c}}$ & SP & Photograph \\
\hline Calonectris diomedea & $\mathrm{RS}$ & Specimen \\
\hline Puffinus boydi & AP to RN (offshore) & RTD position \\
\hline Fregata aquila & $\mathrm{FN}$ & RTD position \\
\hline Morus bassanus & $\mathrm{CE}$ & Photograph \\
\hline
\end{tabular}




\begin{tabular}{|c|c|c|}
\hline Urubitinga solitaria $^{\mathrm{c}}$ & $\mathrm{RR}$ & Photograph \\
\hline Grallaria guatimalensis & $\mathrm{RR}$ & Specimen \\
\hline Grallaricula nana & $\mathrm{RR}$ & Specimen \\
\hline Sclerurus peruvianus & $\mathrm{AM}$ & Specimen \\
\hline Phyllomyias weedeni ${ }^{\mathrm{c}}$ & $\mathrm{AC}$ & Audio \\
\hline Contopus sordidulus & $\mathrm{RR}$ & Photograph, audio, video \\
\hline Muscisaxicola maculirostris ${ }^{\mathrm{c}}$ & $\mathrm{PR}$ & Photograph \\
\hline Muscisaxicola capistratus ${ }^{\mathrm{c}}$ & RS & Photograph \\
\hline Progne dominicensis & $\mathrm{RR}$ to $\mathrm{MG}$ & RTD position \\
\hline Progne cryptoleuca & $\mathrm{PA}$ to $\mathrm{BA}$ & RTD position \\
\hline Catharus aurantiirostris & $\mathrm{RR}$ & Specimen \\
\hline Sturnus vulgaris ${ }^{c}$ & RS & Photograph \\
\hline Icterus galbula $^{\mathrm{c}}$ & $\mathrm{RR}$ & Photograph \\
\hline Parkesia motacilla & $\mathrm{RR}$ & Photograph \\
\hline Mniotilta varia $^{\mathrm{c}}$ & SP & Photograph \\
\hline Leiothlypis peregrina ${ }^{\mathrm{c}}$ & $\mathrm{AM}$ & Photograph \\
\hline Pheucticus ludovicianus $^{\mathrm{c}}$ & MA & Photograph \\
\hline
\end{tabular}

${ }^{a}$ Abbreviations for Brazilian states and archipelagos: AC - Acre; AM - Amazonas; AP Amapá; BA - Bahia; CE - Ceará; FN - Fernando de Noronha Archipelago (part of the state of Pernambuco); MA - Maranhão; MG - Minas Gerais; PA - Pará; PR - Paraná; RJ - Rio de Janeiro; RN - Rio Grande do Norte; RR - Roraima; RS - Rio Grande do Sul; SP - São Paulo; SPSP - São Pedro and São Paulo Archipelago (part of the state of Pernambuco).

${ }^{\mathrm{b}}$ RTD - remote tracking device (or system).

${ }^{\mathrm{c}}$ Records resulting from activities involving citizen scientists.

\section{Additions due to taxonomic splits}

Thirty-five species are added to the list based on splits of species already included in Piacentini et al. (2015). Recent published evidence supports the treatment of these former subspecies as species-level taxa (Table 2; SI).

Table 2 Species recognized in this new edition of the checklist of the birds of Brazil based on the split of polytypic species included in Piacentini et al. (2015). See Supplementary Information for references supporting these taxonomic changes

\section{Current treatment $\quad$ Treatment in Piacentini et al. (2015)}




\begin{tabular}{|c|c|}
\hline Crypturellus zabele & Crypturellus noctivagus zabele \\
\hline Ortalis remota & Ortalis guttata remota \\
\hline Ortalis ruficeps & Ortalis motmot ruficeps \\
\hline Phaethornis major & Phaethornis bourcieri major \\
\hline Campylopterus obscurus & Campylopterus largipennis obscurus \\
\hline Campylopterus diamantinensis & Campylopterus largipennis diamantinensis \\
\hline Tringa inornata & Tringa semipalmata inornata \\
\hline Malacoptila minor & Malacoptila striata minor \\
\hline Megascops ater & Megascops usta \\
\hline Trogon chrysochloros & Trogon rufus chrysochloros \\
\hline Herpsilochmus frater & Herpsilochmus rufimarginatus frater \\
\hline Myrmoborus berlepschi & Myrmoborus lugubris berlepschi \\
\hline Myrmoborus stictopterus & Myrmoborus lugubris stictopterus \\
\hline Pyriglena similis & Pyriglena leuconota similis \\
\hline Pyriglena maura & Pyriglena leuconota maura \\
\hline Melanopareia bitorquata & Melanopareia torquata bitorquata \\
\hline Myrmothera subcanescens & Myrmothera campanisona subcanescens \\
\hline Dendrocincla atrirostris & Dendrocincla fuliginosa atrirostris \\
\hline Dendrexetastes devillei & Dendrexetastes rufigula devillei \\
\hline Dendrexetastes paraensis & Dendrexetastes rufigula paraensis \\
\hline Dendrocolaptes transfasciatus & Dendrocolaptes picumnus transfasciatus \\
\hline Chiroxiphia regina & Chiroxiphia pareola regina \\
\hline Tyrannus monachus & Tyrannus savana monachus \\
\hline Cyphorhinus transfluvialis & Cyphorhinus arada transfluvialis \\
\hline Cyphorhinus modulator & Cyphorhinus arada modulator \\
\hline Cyphorhinus interpositus & Cyphorhinus arada interpositus \\
\hline Cyphorhinus griseolateralis & Cyphorhinus arada griseolateralis \\
\hline Polioptila innotata & Polioptila plumbea innotata \\
\hline Polioptila atricapilla & Polioptila plumbea atricapilla \\
\hline Polioptila parvirostris & Polioptila plumbea parvirostris \\
\hline Turdus arthuri & Turdus ignobilis arthuri \\
\hline Turdus debilis & Turdus ignobilis debilis \\
\hline Arremon polionotus & Arremon flavirostris polionotus \\
\hline Agelasticus atroolivaceus & Agelasticus cyanopus atroolivaceus \\
\hline Caryothraustes brasiliensis & Caryothraustes canadensis brasiliensis \\
\hline
\end{tabular}


In addition, three species listed in Piacentini et al. (2015) are replaced in the present edition after their accepted split because the nominotypical form is extralimital to Brazil: Fregata ariel (replaced with Fregata trinitatis), Megascops guatemalae (replaced with Megascops roraimae) and Turdus ignobilis (replaced with Turdus murinus) (see Supplementary Information for references supporting these taxonomic changes).

\section{Transfers from the Secondary List}

Fifteen species are transferred from the Secondary List of Piacentini et al. (2015) to the Primary List in this new edition because documentary evidence accepted by CBRO has since become available (Table 3).

Table 3 Species upgraded to the Primary List of the Annotated checklist of the birds of Brazil based on transfers from the Secondary List after acceptance of new documentary evidence. The state or archipelago where new documented records occurred are indicated, along with the type of documentary evidence supporting inclusion in the Primary List. New genera for the country shown in bold

\begin{tabular}{|c|c|c|}
\hline Species & State/archipelago $^{\text {a }}$ & Documentary evidence $^{b}$ \\
\hline Geotrygon saphirina & AM & Specimen \\
\hline Cypseloides niger & AM & RTD position, photograph \\
\hline Chaetura pelagica $^{\mathrm{c}}$ & $\mathrm{AC}$ & Photograph \\
\hline Limosa fedoa & MA & Photograph \\
\hline Tringa totanus ${ }^{\mathrm{c}}$ & SP & Photograph \\
\hline Pterodroma madeira & CE to PE (offshore) & RTD position \\
\hline Pterodroma deserta & RS (offshore) & RTD position, photograph \\
\hline Ardea purpurea ${ }^{\mathrm{C}}$ & $\mathrm{FN}$ & Photograph \\
\hline Platalea leucorodia $^{\mathrm{c}}$ & $\mathrm{FN}$ & Photograph \\
\hline Heterocercus aurantiivertex ${ }^{\mathrm{c}}$ & AM & Audio \\
\hline Pipreola whitelyi & $\mathrm{RR}$ & Specimen \\
\hline Knipolegus aterrimus $^{\mathrm{c}}$ & $\mathrm{RS}$ & Photograph \\
\hline Cacicus koepckeae ${ }^{\mathrm{c}}$ & $\mathrm{AC}$ & Audio \\
\hline Setophaga cerulea $^{\mathrm{c}}$ & $\mathrm{SC}$ & Photograph \\
\hline Setophaga virens ${ }^{\mathrm{c}}$ & BA & Photograph \\
\hline
\end{tabular}

${ }^{a}$ Abbreviations for Brazilian states and archipelagos: AC - Acre; AM - Amazonas; BA -

Bahia; CE - Ceará; FN - Fernando de Noronha Archipelago (part of the state of Pernambuco); MA - Maranhão; PE - Pernambuco; RR - Roraima; RS - Rio Grande do Sul; SC - Santa Catarina; SP - São Paulo. 
${ }^{\mathrm{b}}$ RTD - remote tracking device (or system).

${ }^{\mathrm{c}}$ Records resulting from activities involving citizen scientists.

\section{Removals}

Four species (Picumnus fulvescens, Celeus grammicus, Sporophila melanops and Lanio nattereri) are removed from the list due to taxonomic synonymizations (see Supplementary Information). In addition, the following species listed in Piacentini et al. (2015) are treated here as subspecies due to taxonomic "lumps": Chaetura viridipennis, Caracara cheriway, Hylexetastes brigidai, and Serpophaga munda (see Supplementary Information for references supporting these taxonomic changes).

\section{Changes in the Secondary List}

In this new edition, the only addition to the Secondary List is the Black-throated Hermit, Phaethornis atrimentalis, which has been recently observed (by an ornithologist) at Tabatinga, Amazonas. Eleven species are now considered on the Secondary List because their occurrence in Brazil is based solely on sight records or reported captures that lack documentary evidence (SI).

The following five species included in the Secondary list in Piacentini et al. (2015) are moved to the Tertiary List following a re-evaluation of the available evidence: Pterodroma hasitata, Puffinus assimilis, Vultur gryphus, Leucocarbo bransfieldensis, and Protonotaria citrea.

\section{Changes in the genus level}

Forty-two genera are added to the Primary List in this new edition to reflect the conclusions of recent phylogenies and traditional taxonomic work, or to accommodate some new occurrences recently documented for the country. Fifteen newly described genera are adopted here following studies that support the treatment of a number of species in a genus different from that in which they appeared in the previous list due to non-monophyly (SI). This resulted in the change of 21 names at the species level (Table 4).

Table 4 Newly described genera and the species included therein in this new edition of the checklist of the birds of Brazil. To facilitate comparison, the treatment followed in the last version of the checklist (Piacentini et al. 2015) is indicated. See Supplementary Information for references supporting changes in intergeneric limits

Current treatment $\quad$ Treatment in Piacentini et al. (2015)




\begin{tabular}{|c|c|}
\hline Paraclaravis geoffroyi & Claravis geoffroyi \\
\hline Phyllaemulor bracteatus & Nyctibius bracteatus \\
\hline Elliotomyia chionogaster & Amazilia chionogaster \\
\hline Paragallinula angulata & Gallinula angulata \\
\hline Sakesphoroides cristatus & Sakesphorus cristatus \\
\hline Radinopsyche sellowi & Herpsilochmus sellowi \\
\hline Cryptopezus nattereri & Hylopezus nattereri \\
\hline Pseudopipra pipra & Dixiphia pipra \\
\hline Guyramemua affine ${ }^{\mathrm{a}}$ & Suiriri affinis \\
\hline Scotomyias roraimae & Myiophobus roraimae \\
\hline Syrtidicola fluviatilis & Muscisaxicola fluviatilis \\
\hline Asemospiza obscura ${ }^{\text {a }}$, A. fuliginosa $^{\text {a }}$ & Tiaris obscurus, T. fuliginosus \\
\hline Maschalethraupis surinamus & Lanio surinamus \\
\hline Castanozoster thoracicus ${ }^{\text {a }}$ & Poospiza thoracica \\
\hline Stilpnia cyanoptera ${ }^{\mathrm{b}}$, S. nigrocincta, & Tangara argentea, $T$. nigrocincta, $T$. \\
\hline S. cyanicollis, $S$. peruviana, $S$. & cyanicollis, T. peruviana, T. preciosa, $T$. \\
\hline preciosa, $S$. cayana & cayana \\
\hline
\end{tabular}

a Specific name altered to be in grammatical agreement with the new genus.

${ }^{\mathrm{b}}$ Specific name reverted from argentea to cyanoptera because homonymy was no longer an issue in the genus Stilpnia.

Another 21 genera, described more than three decades ago, are restored as a result of divisions and rearrangements of other genera, resulting in changes to 42 names at the species level (Table 5). At least three of these genera (Heteroxolmis, Leistes and Thraupis) have been featured in several articles and reference works in recent decades. New documented occurrences for the country account for the other six newly included genera (Tables 1 and 3).

Table 5 Restored genera and species included therein in this new edition of the checklist of the birds of Brazil. To facilitate comparison, the treatment followed in the last version of the checklist (Piacentini et al. 2015) is indicated. See Supplementary information for references supporting changes in intergeneric limits

\begin{tabular}{ll}
\hline Current treatment & Treatment in Piacentini et al. (2015) \\
\hline Spatula versicolor, S. platalea, $S$. & Anas versicolor, A. platalea, A. discors, $A$. \\
discors, S. cyanoptera & cyanoptera
\end{tabular}


Mareca sibilatrix

Thalaphorus chlorocercus

Saucerottia viridigaster

Chionomesa fimbriata, C. lactea

Rufirallus viridis

Hydrobates leucorhous ${ }^{\text {a }}$

Ardenna tenuirostris, $A$. grisea ${ }^{\mathrm{a}}, A$. gravis

Hieraspiza superciliosa ${ }^{\text {a }}$

Cyphos macrodactylus

Tamatia tamatia

Dendroma rufa ${ }^{\text {a }}$, D. erythroptera ${ }^{\text {a }}$

Heteroxolmis dominicanus

Nengetus cinereus, $N$. coronatus, $N$.

rubetra, N. rufiventris

Cyanophonia cyanocephala

Leistes militaris, L. superciliaris, $L$. defilippii

Loriotus luctuosus, L. cristatus, $L$. rufiventer

Rauenia bonariensis

Diuca diuca

Ixothraupis varia, I. punctata, I. guttata,

I. xanthogastra

Thraupis episcopus, T. sayaca, $T$. cyanoptera, T. palmarum, T. ornata
Anas sibilatrix

Leucippus chlorocercus

Amazilia viridigaster

Amazilia fimbriata, Amazilia lactea

Laterallus viridis

Oceanodroma leucorhoa

Puffinus tenuirostris, $P$. griseus, $P$. gravis

Accipiter superciliosus

Bucco macrodactylus

Bucco tamatia

Philydor rufum, P. erythropterum

Xolmis dominicanus

Xolmis cinereus, $X$. coronatus, $X$. rubetra,

Neoxolmis rufiventris

Euphonia cyanocephala

Sturnella militaris, $S$. superciliaris, $S$.

defilippii

Lanio luctuosus, L. cristatus, L. rufiventer

Pipraeidea bonariensis

Hedyglossa diuca

Tangara varia, T. punctata, T. guttata, T.

xanthogastra

Tangara episcopus, T. sayaca, T. cyanoptera,

T. palmarum, T. ornata

${ }^{\text {a }}$ Specific name altered to be in grammatical agreement with the new genus.

In addition, 11 species are transferred to seven genera already included in the previous edition of the list, expanding the group of species subordinate to them (Table 6).

Table 6 Species transferred in this new edition of the checklist of the birds of Brazil to genera already included in the last version of the checklist (Piacentini et al. 2015). See Supplementary information for references supporting changes in intergeneric limits 


\begin{tabular}{|c|c|}
\hline Current treatment & Treatment in Piacentini et al. (2015) \\
\hline Chrysuronia versicolor, C. rondoniae, & Amazilia versicolor, A. rondoniae, A. brevirostris, \\
\hline C. brevirostris, C. leucogaster & A. leucogaster \\
\hline Chlorestes cyanus & Hylocharis cyanus \\
\hline Laterallus flaviventer, L. spilopterus a & Porzana flaviventer, $P$. spiloptera \\
\hline Myrmothera berlepschi & Hylopezus berlepschi \\
\hline Limnoctites sulphuriferus a & Cranioleuca sulphurifera \\
\hline Cacicus solitarius & Procacicus solitarius \\
\hline Thlypopsis pyrrhocoma ${ }^{\mathrm{b}}$ & Pyrrhocoma ruficeps \\
\hline
\end{tabular}

${ }^{a}$ Specific name altered to be in grammatical agreement with the new genus.

${ }^{\mathrm{b}}$ Specific name replaced to prevent homonymy in the genus Thlypopsis.

The adoption of the new combinations above resulted in the exclusion of seven genera from the Primary List: Leucippus, Amazilia, Oceanodroma, Neoxolmis, Procacicus, Pyrrhocoma, and Hedyglossa.

\section{Changes in intraspecific arrangement}

A number of species had their taxonomic status altered from polytypic (with subspecies) to monotypic (without subspecies) or vice versa (Table 7), due to the splitting, lumping or synonymization of taxa, or simply to correct previous mistakes (see also Table 2).

Table 7 Species that had their taxonomic status changed to either polytypic or monotypic in the present edition of the checklist of the birds of Brazil. See Supplementary Information for references supporting these changes

\begin{tabular}{lc}
\hline Species & Current status \\
\hline Crypturellus noctivagus & Monotypic \\
Penelope obscura & Monotypic \\
Ortalis motmot & Monotypic \\
Chaetura chapmani & Polytypic \\
Phaethornis bourcieri & Monotypic \\
Campylopterus largipennis & Monotypic \\
Numenius hudsonicus & Monotypic \\
Gallinago paraguaiae & Monotypic
\end{tabular}




\begin{tabular}{|c|c|}
\hline Tringa semipalmata & Monotypic \\
\hline Xema sabini ${ }^{\mathrm{a}}$ & Polytypic \\
\hline Gygis alba & Monotypic \\
\hline Thalasseus maximus & Monotypic \\
\hline Eudyptes chrysocome & Monotypic \\
\hline Pterodroma macroptera & Monotypic \\
\hline Puffinus puffinus & Polytypic \\
\hline Malacoptila striata & Monotypic \\
\hline Celeus undatus & Monotypic \\
\hline Caracara plancus & Polytypic \\
\hline Aratinga auricapillus & Monotypic \\
\hline Dendrexetastes rufigula & Monotypic \\
\hline Hylexetastes uniformis & Polytypic \\
\hline Tarphonomus certhioides ${ }^{\mathrm{a}}$ & Polytypic \\
\hline Ancistrops strigilatus $^{\mathrm{a}}$ & Polytypic \\
\hline Automolus subulatus ${ }^{\mathrm{a}}$ & Polytypic \\
\hline Asthenes pyrrholeuca ${ }^{\text {a }}$ & Polytypic \\
\hline Chiroxiphia pareola & Monotypic \\
\hline Procnias albus & Monotypic \\
\hline Mionectes roraimae & Monotypic \\
\hline Euscarthmus meloryphus & Monotypic \\
\hline Tyranniscus burmeisteri ${ }^{\text {a }}$ & Polytypic \\
\hline Sirystes sibilator & Monotypic \\
\hline Tyrannus savana & Monotypic \\
\hline Tyrannus dominicensis ${ }^{\text {a }}$ & Polytypic \\
\hline Agriornis micropterus ${ }^{\text {a }}$ & Polytypic \\
\hline Cyphorhinus arada & Monotypic \\
\hline Polioptila plumbea & Monotypic \\
\hline Turdus iliacus ${ }^{\mathrm{a}}$ & Polytypic \\
\hline Arremon taciturnus & Monotypic \\
\hline Arremon flavirostris & Monotypic \\
\hline Agelasticus cyanopus & Monotypic \\
\hline Sporophila maximiliani & Monotypic \\
\hline Poospiza nigrorufa & Monotypic \\
\hline
\end{tabular}

${ }^{\text {a }}$ Species erroneously listed as monotypic in Piacentini et al. (2015). 


\section{Changes at family level}

A new family is recognized in this new version of the checklist (Oceanitidae), split off from Hydrobatidae. In Piacentini et al. (2015), this set of pelagic birds was treated as a subfamily. In addition, Pelecanoididae has been dissolved and incorporated into the Procellariidae. A second family added to the List (Sturnidae) derives from the recent range expansion of Sturnus vulgaris from Uruguay. This is an invasive Old World species, which has been introduced in several parts of the Americas.

The current edition includes 85 subfamilies, as compared to 56 in Piacentini et al. (2015). Thirty-one subfamilies are added to the present edition of the checklist (Table 8), whereas two subfamilies previously grouped in Hydrobatidae (Hydrobatinae and Oceanitinae) are removed. Two of the current subfamilies in Laridae (Rynchopinae and Sterninae) were considered at the family level in Piacentini et al. (2015).

Table 8 Subfamilies added to this new edition of the checklist of the birds of Brazil, with the respective families to which they are subordinate

\begin{tabular}{ll}
\hline Subfamily & Grouping family \\
\hline Columbinae & Columbidae \\
Claravinae & Columbidae \\
Florisuginae & Trochilidae \\
Polytminae & Trochilidae \\
Lesbiinae & Trochilidae \\
Numeniinae & Scolopacidae \\
Limosinae & Scolopacidae \\
Arenariinae & Scolopacidae \\
Scolopacinae & Scolopacidae \\
Tringinae & Scolopacidae \\
Anoinae & Laridae \\
Gyginae & Laridae \\
Rynchopinae & Laridae \\
Larinae & Laridae \\
Sterninae & Laridae \\
Elaninae & Accipitridae \\
Gypaetinae & Accipitridae \\
Accipitrinae & Accipitridae \\
Chelidopterinae & Bucconidae \\
Bucconinae & Bucconidae
\end{tabular}




\begin{tabular}{ll} 
Picumninae & Picidae \\
Picinae & Picidae \\
Herpetotherinae & Falconidae \\
Caracarinae & Falconidae \\
Falconinae & Falconidae \\
Arinae & Psittacidae \\
Dolichonychinae & Icteridae \\
Sturnellinae & Icteridae \\
Cacicinae & Icteridae \\
Icterinae & Icteridae \\
Agelainae & Icteridae \\
\hline
\end{tabular}

\section{Changes in the systematic sequence}

Several changes in the systematic sequence of orders and families between this new edition and Piacentini et al. (2015) can be tracked by comparing the systematic synopses of both editions (see Supplementary Information). However, the sequence of the first four orders and the final position of the Passeriformes remain unchanged. Within families, changes in the sequence of genera and species are implemented especially in the Columbidae, Trochilidae, Rallidae, Accipitridae, Bucconidae, Picidae, Psittacidae, Tyrannidae (Fluvicolinae), Icteridae, and Thraupidae (Supplementary Information).

\section{Nomenclatural changes}

Certain changes implemented in this list are of a merely nomenclatural nature, as required by the International Code of Zoological Nomenclature (ICZN 1999), and therefore do not change the sum totals (Table 9; see Supplementary Information for details).

Table 9 Species names or authorship changed in this new edition of the checklist according to the rules of the International Code of Zoological Nomenclature to amend previous nomenclatural inconsistencies

\begin{tabular}{ll}
\hline Current treatment & Treatment in Piacentini et al. (2015) \\
\hline Porphyrio martinica & Porphyrio martinicus \\
Nannopterum brasilianum & Nannopterum brasilianus \\
Pyrrhura pallescens & Pyrrhura snethlageae \\
Clibanornis watkinsorum & Clibanornis watkinsi \\
Ramphocelus bresilia & Ramphocelus bresilius \\
\hline
\end{tabular}




\section{Discussion}

The Primary List of this new edition of the Annotated Checklist of the birds of Brazil, with 1971 recognized species, represents a net increase of 82 species (or 4.3\%) compared to the previous edition (Piacentini et al. 2015). More precisely, 90 species have been added and eight removed. The majority of additions result from new occurrences $(n=35)$ and from the elevation of subspecies to species rank $(n=35)$. Another 15 species added result from transfers to the Primary List due to the availability of new documentary evidence. Finally, five species have been described since the publication of the previous edition of the list.

In recent years, ornithological knowledge in Brazil has benefited from the increasing contribution of citizen scientists in documenting new occurrences for the country and in obtaining valid documentary evidence for previously unconfirmed species, especially through photographic records. Of the 50 species that represent new occurrences or have recently been transferred to the Primary List, more than half (54\%) came from the activity of this group of contributors.

Comparison with the last edition of the list also shows a small change in the number of polytypic species (905 vs 910 in Piacentini et al. 2015) and of valid or potentially valid taxa, including both species and subspecies (3064 vs 3051).

Of the total Brazilian species, 1742 breed or are assumed to breed in the country (293 of which are endemic to Brazil), 126 regularly occur as non-breeding visitors and 103 have been recorded only occasionally and are regarded as vagrants. The most pronounced increase (56\%) was seen in the number of vagrant species, from 66 in Piacentini et al. (2015) to just over one hundred in this updated list. The distinction between vagrants from the north and east, implemented for the first time in this edition of the list, provides a more accurate picture of the origin of these species and shows that more than half of the boreal vagrants recorded in the country come from the Palearctic ( 29 vs 23 of Nearctic or Caribbean origin, plus five species of uncertain origin).

The number of endemic species in Brazil increased by 19 compared to Piacentini et al. (2015) as a result of taxonomic splits $(n=15)$ and four new species descriptions (Campylopterus calcirupicola, Megascops stangiae, M. alagoensis, and Trogon muriciensis), currently standing at 293. This number places Brazil in third place among the countries with the largest number of endemic bird species in the world, behind only Indonesia and Australia, both island countries (IUCN 2020). However, four Brazilian endemics are already extinct, at least in the wild: Cyanopsitta spixii, Glaucidium mooreorum, Cichlocolaptes mazarbarnetti and Philydor novaesi (ICMBio 2018).

As already mentioned in the previous edition, we have not included in the checklist some species that have occurred, or even breed, in the country, but which are known or are 
assumed to have arrived in Brazil with the assistance of humans, such as Pycnonotus jocosus (Pycnonotidae) and Corvus albus (Corvidae) (Silva e Silva and Olmos 2007; Serpa 2008; Lima and Kamada 2009). Such species may eventually be accepted as belonging to the Brazilian avifauna (as introduced species) if self-sustaining populations become established in the country, as recognized since the last century for species such as Columba livia, Estrilda astrild, and Passer domesticus.

One relatively recent occurrence (Sturnus vulgaris) refers to a European species introduced in Argentina, which has now spread into Brazil in Rio Grande do Sul state (Silva et al. 2017). Like the European Goldfinch (Carduelis carduelis), another exotic species recently recorded in the country, the European Starling is already expanding northwards and may soon colonize other parts of Brazil. With the addition of this species, the number of alien bird species with naturalized populations in Brazil rises to five.

The steady increase in the Brazilian avian checklist over the years and the considerable leap in species added with this latest installment make it clear that we are still far from cataloging the true bird diversity of the country. New species continue to be described in parallel with numerous taxonomic splits, in addition to a constant stream of new records for the country, which are typically the main source of additions in regions with better-known avifaunas. Thus, there is clearly still a need for responsible collecting and for trained taxonomists, a profession in decline throughout the world. At the same time, an impressive contribution can be recognized from the documentation available on public, collaborative data platforms, especially photographs and voice recordings made by citizen scientists who contribute not only physical evidence of the presence of species, but also the raw materials for future analyses of taxonomic status. Now more than ever, the science of ornithology and the popular activity of bird watching contribute to one another in a positive feedback of increasing knowledge that we hope this list stimulates even more.

Acknowledgments We dedicate this new edition of the Annotated Checklist of the birds of Brazil to the memory of Walter Adolfo Voss (1933-2020), honorary member of the CBRO. We thank the following friends and colleagues who have pointed out inconsistencies in previous versions of the checklist: Bret M. Whitney, Guy M. Kirwan, J.V. Remsen, Jeremy Minns, Luis A. Florit, Normand David, Rafael D. Lima, Weber Girão and, especially, for her meticulous review, Summer V. Wilson. Many other individuals generously provided unpublished information that significantly contributed to the work of the Subcommittee on Taxonomy and for the preparation of the explanatory notes (the species involved are mentioned after each name): Albano Schulz Neto (Platalea leucorodia), Andrew Whittaker (Muscisaxicola maculirostris), Antônio C. de Brum (Chroicocephalus ridibundus), Arthur Gomes (Contopus sordidulus), Brad Winn (Limnodromus griseus hendersoni), Bret M. Whitney (Cacicus 
koepckeae, Leiothlypis peregrina, Cypseloides niger), Carlos O. A. Gussoni (Icterus galbula), Chris Farias (M. maculirostris), Dante R. C. Buzzetti (C. koepckeae, Phyllomyias weedeni), Fernanda Hoppen (Tringa totanus), Fernando Díaz Segovia (M. maculirostris), Gabriel A. Leite (C. sordidulus, Phaethornis atrimentalis), John Thompson (I. galbula), Marcelo Holderbaum (Limosa fedoa), Márcio Repenning (Sporophila iberaensis), Michael O'Brien (L. g. hendersoni), Renata N. Biancalana (Chaetura pelagica), Ronaldo Lebowski (Mniotilta varia), and Sergio R. Porto (Calidris mauri). We also thank Thiago Vernaschi, Summer V. Wilson and two anonymous reviewers for their helful corrections and suggestions, which significantly improved the manuscript of this new edition of the checklist. Finally, the following funding agencies supported several of us with both fellowships and research grants, which were essential to complete successfully the present work: Fundação de Amparo à Pesquisa do Estado de São Paulo (FAPESP), Conselho Nacional de Desenvolvimento Científico e Tecnológico (CNPq), and Coordenação de Aperfeiçoamento de Pessoal de Nível Superior (CAPES).

\section{Declarations}

Funding: Some of the authors received support from Fundação de Amparo à Pesquisa do Estado de São Paulo (FAPESP), Conselho Nacional de Desenvolvimento Científico e Tecnológico (CNPq), and Coordenação de Aperfeiçoamento de Pessoal de Nível Superior (CAPES).

Conflicts of interest: The authors have no financial or proprietary interests in any material presented in this article.

Availability of data: An Excel worksheet of the checklist is publicly available in the Zenodo repository.

\section{References}

Aleixo A (2007) Conceitos de espécie e o eterno conflito entre continuidade e operacionalidade: uma proposta de normatização de critérios para o reconhecimento de espécies pelo Comitê Brasileiro de Registros Ornitológicos. Rev Bras Ornitol 15:297-310

Carlos CJ, Straube FC, Pacheco JF (2010) Conceitos e definições sobre documentação de registros ornitológicos e critérios para a elaboração de listas de aves para os estados brasileiros. Rev Bras Ornitol 18:355-361

Carvalho GLC (1999) O mar territorial brasileiro de 200 milhas: estratégia e soberania, 19701982. Rev Bras Polit Int 42:110-126

Clements JF, Schulenberg TS, Iliff MJ, Billerman SM, Fredericks TA, Sullivan BL, Wood CL (2019) The eBird/Clements Checklist of Birds of the World: v2019https://www.birds.cornell.edu/clementschecklist/download/ Accessed 30 September 2020 
de Queiroz K (2005) Ernst Mayr and the modern concept of species. Proc Natl Acad Sci USA 102:6600-6607. https://doi.org/10.1073/pnas.0502030102

del Hoyo J, Collar NJ, Christie DA, Elliot A, Fishpool LDC (2014) HBW and BirdLife International illustrated checklist of the birds of the world, vol. 1, non-passerines. Lynx Editions, Barcelona

del Hoyo J, Collar NJ, Christie DA, Elliot A, Fishpool LDC, Boesman P, Kirwan GM (2016) HBW and BirdLife International illustrated checklist of the birds of the world, vol. 2, Passerines. Lynx Editions, Barcelona

del Hoyo J, Elliott A, Sargatal J, Cabot J, Christie DA (eds) (1992-2013) Handbook of the birds of the world, 17 vols. Lynx Editions, Barcelona

Dickinson EC, Christidis L (2014) The Howard \& Moore complete checklist of the birds of the world, vol. 2, passerines. Aves Press, Eastbourne

Dickinson EC, Remsen JV (2013) The Howard and Moore complete checklist of the birds of the world, vol. 1, non-passerines. Aves Press, Eastbourne

Fattorini S (2017) Endemism in historical biogeography and conservation biology: concepts and implications. Biogeographia 32:47-75

Franz I, Agne CE, Bencke GA, Bugoni L, Dias RA (2018) Four decades after Belton: a review of records and evidences on the avifauna of Rio Grande do Sul, Brazil. Iheringia, Ser Zool 108:1-38. https://doi.org/10.1590/1678-4766E2018005

Fuchs J, Pons J-M (2015) A new classification of the Pied Woodpeckers assemblage (Dendropicini, Picidae) based on a comprehensive multi-locus phylogeny. Mol Phylogenet Evol 88:28-37. https://doi.org/10.1016/j.ympev.2015.03.016

Gill F (2014) Species taxonomy of birds: which null hypothesis? Auk 131:150-161. https://doi.org/10.1642/auk-13-206.1

Gill F, Donsker D, Rasmussen P (eds) (2020) IOC world bird list (v10.2). https://doi.org/10.14344/IOC.ML.10.2

Grantsau R (2010) Guia completo para identificação das aves do Brasil, 2 vols. Vento Verde, São Carlos

Hellmayr CE (1927) Catalogue of birds of the Americas and the adjacent islands, Part V. Field Museum of Natural History, Chicago

ICMBio [Instituto Chico Mendes de Conservação da Biodiversidade] (2018) Livro vermelho da fauna brasileira ameaçada de extinção, vol I/1. ICMBio, Brasília

ICZN [International Commission on Zoological Nomenclature] (1999) International Code of Zoological Nomenclature, 4th edn. ICZN, London

IUCN [International Union for Conservation of Nature] (2020) The IUCN red list of threatened species. Version 2020-3. https://www.iucnredlist.org/resources/summarystatistics\#Summary\%20Tables. Accessed 27 February 2021 
Lima B, Kamada B (2009) Registros de corvo-bicolor Corvus albus (Passeriformes: Corvidae) em território brasileiro. Atualidades Ornitol 150:10-11

Mallet-Rodrigues F, Gonzaga LP (2015) Geographic variation in plumage coloration of Turquoise Tanager Tangara mexicana (Linnaeus, 1766). Rev Bras Ornitol 23:341-350. https://doi.org/10.1007/BF03544303

Manthey JD, Campillo LC, Burns KJ, Moyle RG (2016) Comparison of target-capture and restriction-site associated DNA sequencing for phylogenomics: a test in cardinalid tanagers (Aves, Genus: Piranga). Syst Biol 65:640-650. https://doi.org/10.1093/sysbio/syw005

Marra PP, Cohen E, Harrison A-L (2018) Migratory connectivity. In: Choe J (ed) Encyclopedia of animal behavior, 2nd edn. Academic Press, Cambridge. https://doi.org/10.1016/B978-012-809633-8.20761-9

Musher LJ, Cracraft J (2018) Phylogenomics and species delimitation of a complex radiation of Neotropical suboscine birds (Pachyramphus). Mol Phylogenet Evol 118:204-221. https://doi.org/10.1016/j.ympev.2017.09.013

Nunes AP, Straube FC, Laps RR, Posso SR (2017) Checklist das aves do estado do Mato Grosso do Sul, Brasil. Iheringia, Ser Zool 107:e2017154. https://doi.org/10.1590/16784766E2017154

Ohlson JI, Irestedt M, Ericson PGP, Fjeldså J (2013) Phylogeny and classification of the New World suboscines (Aves, Passeriformes). Zootaxa 3613:1-35. https://doi.org/10.11646/zootaxa.3613.1.1

Ottenburghs J, Kraus RHS, van Hooft P, van Wieren SE, Ydenberg RC, Prins HHT (2017) Avian introgression in the genomic era. Avian Res 8:30. https://doi.org/10.1186/s40657017-0088-z

Padial JM, De la Riva I (2020) A paradigm shift in our view of species drives current trends in biological classification. Biol Rev 96:731-751. https://doi.org/10.1111/brv.12676

Peterson AT, Watson DM (1998) Problems with areal definitions of endemism: the effects of spatial scaling. Divers Distrib 4:189-194. https://doi.org/10.1046/j.1472-

4642.1998.00021.x

Piacentini VQ, Aleixo A, Agne CE, Maurício GN, Pacheco JF, Bravo GA, Brito GRR, Naka LN, Olmos F, Posso S, Silveira LF, Betini GS, Carrano E, Franz I, Lees, AC, Lima LM, Pioli D, Schunck F, Amaral FR, Bencke GA, Cohn-Haft M, Figueiredo LFA, Straube FC, Cesari E (2015) Annotated checklist of the birds of Brazil by the Brazilian Ornithological Records Committee. Rev Bras Ornitol 23:91-298. https://doi.org/10.1007/BF03544294

Remsen JV, Areta JI, Bonaccorso E, Claramunt S, Jaramillo A, Pacheco JF, Robbins MB, Stiles FG, Stotz DF, Zimmer KJ (2021) A classification of the bird species of South America. American Ornithological Society. Version: 19 January 2021. http://www.museum.lsu.edu/ Remsen/SACCBaseline.htm 
Ridgway R (1901) The birds of North and Middle America: a descriptive catalogue of the higher groups, genera, species, and subspecies of birds known to occur in North America, from the Arctic lands to the Isthmus of Panama, the West Indies and other islands of the Caribbean sea, and the Galapagos Archipelago. Pt 1. Bull US Natl Mus 50:1-715

Sangster, G (2018) Integrative taxonomy of birds: the nature and delimitation of species. In: Tietze D (ed) Bird species. Fascinating life sciences. Springer, Cham. https://doi.org/10.1007/978-3-319-91689-7_2

Schultz, ED, Pérez-Emán J, Aleixo A, Myiaki CY, Brumfield RT, Cracraft J, Ribas CC (2019) Diversification history in the Dendrocincla fuliginosa complex (Aves: Dendrocolaptidae): Insights from broad geographic sampling. Mol Phylogenet Evol 140:106581. https://doi.org/10.1016/j.ympev.2019.106581

Serpa GA (2008) Primeiros registros da introdução e reprodução do bulbul-de-bigode-vermelho Pycnonotus jocosus (Pycnonotidae) em território brasileiro. Atualidades Orn 141:12-13

Sick H (1997) Ornitologia brasileira. Nova Fronteira, Rio de Janeiro

Silva FC, Pinto JM, Mäder A, Souza VAT (2017) First records of European Starling Sturnus vulgaris in Brazil. Rev Bras Ornitol 25:291-292. https://doi.org/10.1007/BF03544409

Silva e Silva R, Olmos F (2007) Adendas e registros significativos para a avifauna dos manguezais de Santos e Cubatão, SP. Rev Bras Ornitol 15:551-560

Straube FC (2003) Bases legais para a identificação dos limites territoriais do Brasil na fronteira com o Paraguai e suas implicações para a consideração de registros ornitológicos. Ararajuba 11:131-135

Tello JG, Moyle RG, Marchese DJ, Cracraft J (2009) Phylogeny and phylogenetic classification of the tyrant flycatchers, cotingas, manakins, and their allies (Aves: Tyrannides). Cladistics 25:429-467. https://doi.org/10.1111/j.1096-0031.2009.00254.x 